\title{
Cyclization of Multi Components Reactions and (Preparation, Investigation, Thermal Curves)
}

\author{
Nagham Mahmood Aljamali ${ }^{1}$, Nour Abd Alrazzak Abd Allattif ${ }^{2} \&$ Sabreen Ali Abdalrahman ${ }^{3}$ \\ ${ }^{\mathbf{1}}$ Department of Chemistry, Faculty of Education for Girls, Kufa University, Iraq \\ ${ }^{2}$ Department of Chemistry, College of Science for Women, University of Babylon, Iraq \\ ${ }^{3}$ B.Sc in Chemistry, Kufa University, Iraq
}

Correspondence: Dr. Nagham Mahmood Aljamali. Department of Chemistry, Faculty of Education for Girls, Kufa University, Iraq. Email: Dr.Nagham_mj@yahoo.com

Received: August 29, 2018

Accepted: September 23, 2018

Online Published: October 10, 2018

DOI: $10.54655 /$ aijmsr.v2n1p1

\begin{abstract}
Many cyclic compounds were formatted via multi components reactions and cyclization reaction through many steps with (various conditions, various starting materials, various components ), in first step, aromatic amine derivative were reacted with ammonium thiocyanate in cyclization reaction to yield 2aminobenzothiazole derivative, which reacted with formaldehyde and benzaldehyde as a multi components reaction ., then the resulting compounds cyclized with ( semicarbazide, ortho-phenyl diamine, ortho-thiol aniline , ortho- amino phenol ). Investigation of compounds carried out through many techniques ( FT.IR , H.NMR , Mass ) - Spectra , Thermal studies
\end{abstract}

Keywords: Multi Components, Cyclization, Heterocyclic ,Oxadiazole, Imidazole, Thiazole, Oxazole.

Introduction

A heterocyclic compounds are a cyclic compound which have at least two different elements or more as members of its structure. Heterocyclic chemistry is the branch of synthetic chemistry dealing with the preparation ${ }^{(1-3)}$, ${\text { characterization } \text { uses }^{(4-6)} \text {, applications }}^{(7-9)}$ of these compounds that include all of the nucleic acids, drugs, cellulose and many natural and industrial dyes ${ }^{(10-12)}$. 


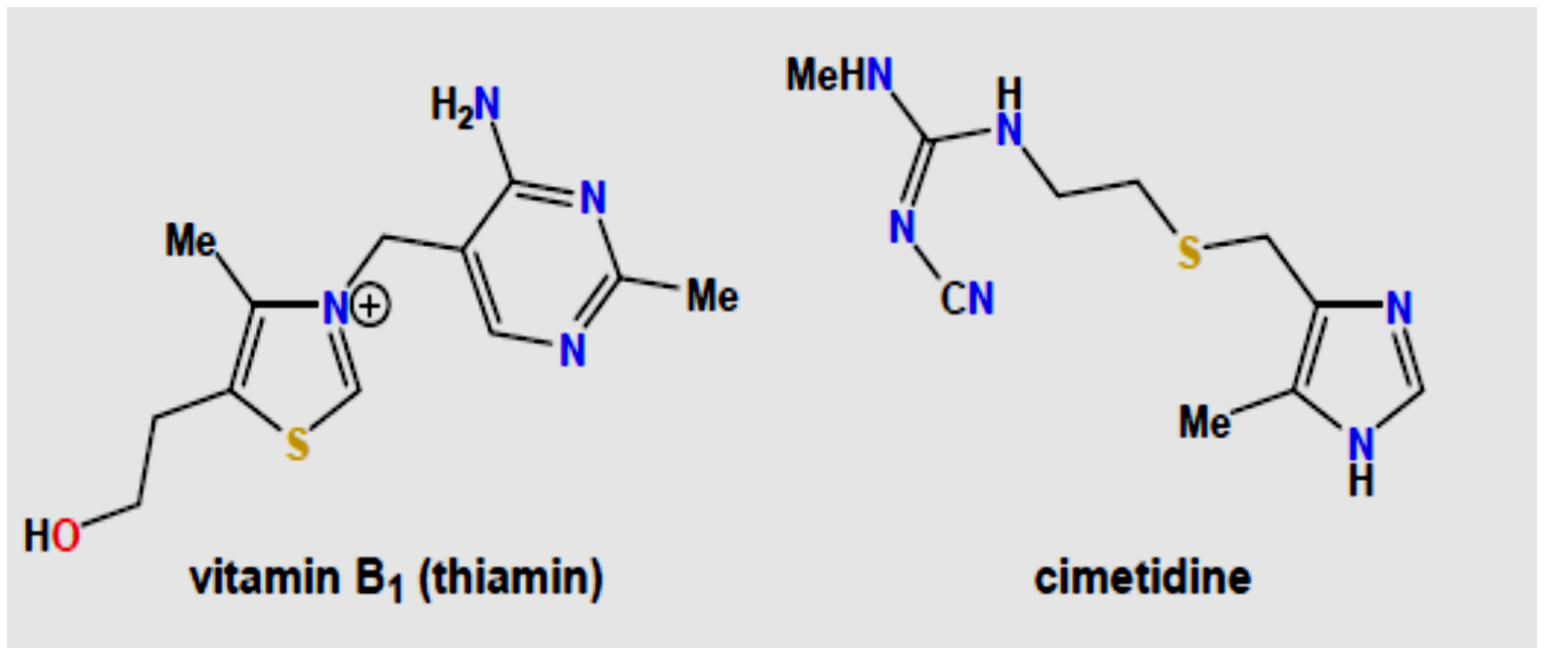

Fig.(1): Heterocycle compounds as a drugs

Heterocyclic derivatives have a wide range of uses $^{(13-15)}$ and applications ${ }^{(16-19)}$ in pharmaceutical chemistry ${ }^{(20-}$ ${ }^{24)}$, which involved many ${ }^{(25-28)}$ of the biochemical material essential to bio- molecules like vitamins , nucleic acids, the chemical materials ${ }^{(29-31)}$ that carry the genetic information controlling inheritance, include a long chains of heterocyclic units held together by other types ${ }^{(32-36)}$ of substances . Many naturally occurring dyes , pigments, vitamins, and antibiotics are heterocyclic compounds ${ }^{(37-40)}$.

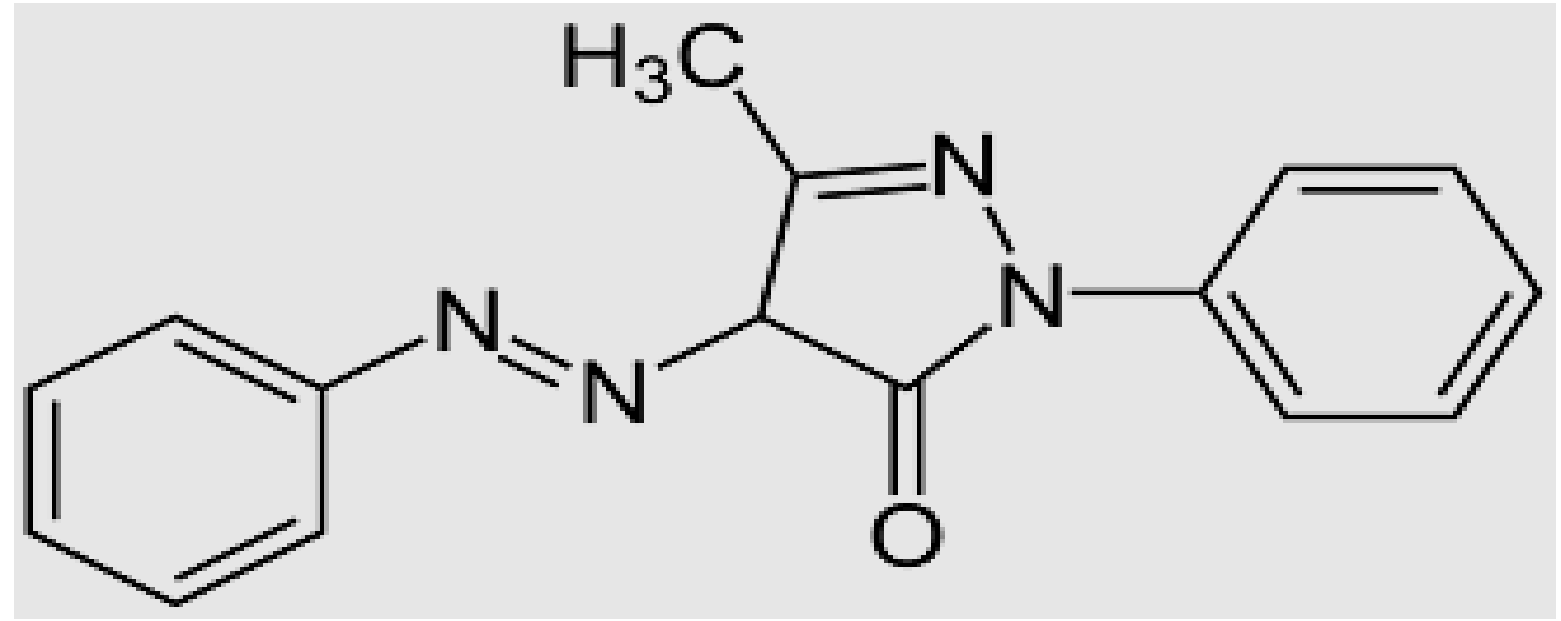

Fig.(2): Heterocyclic compound as a dye

Experimental Part

Allcompounds were investigation through : FT-IR spectra (FT-IR 8300 Shimadzu) in the range (400-4000) $\mathrm{cm}^{-1}$ asKBr discs ., 1H.NMR-Spectra in DMSO-solvent., Mass spectra, thermal studying, solubility test, physical properties :

\section{Procedures}

Synthesis of Compounds $\{1,2\}$

p-Amino benzoic acid $\left(0.1\right.$ mole) reacted with ammonium thiocyanate $(0.1 \mathrm{~mole})$ with $(7 \mathrm{ml})$ of $\left(\mathrm{Br}_{2}\right)$ drop by drop with $(5 \mathrm{ml})$ of glacial acetic acid with rotation for $(3 \mathrm{hrs})$ at $\left(10 \mathrm{C}^{\circ}\right)$ according to literatures ${ }^{(21,23)}$, the resulting compound $(0.2$ mole) reacted with $(0.1 \mathrm{m0le})$ of formaldehyde with rotation for $(4 \mathrm{hrs})$ in acid medium $(3 \mathrm{ml})$ $\left(\mathrm{HCl}\right.$ or $\left.\mathrm{H}_{2} \mathrm{SO}_{4}\right)$ to give compound $\{1\}$., which dissolved in $(5 \% \mathrm{NaOH})$ solution then reacted with furfural at room temperature and rotation for ( $5 \mathrm{hrs}$ ), then filtered, dried and re crystallized from ethanol to yield compound $\{2\}$. 


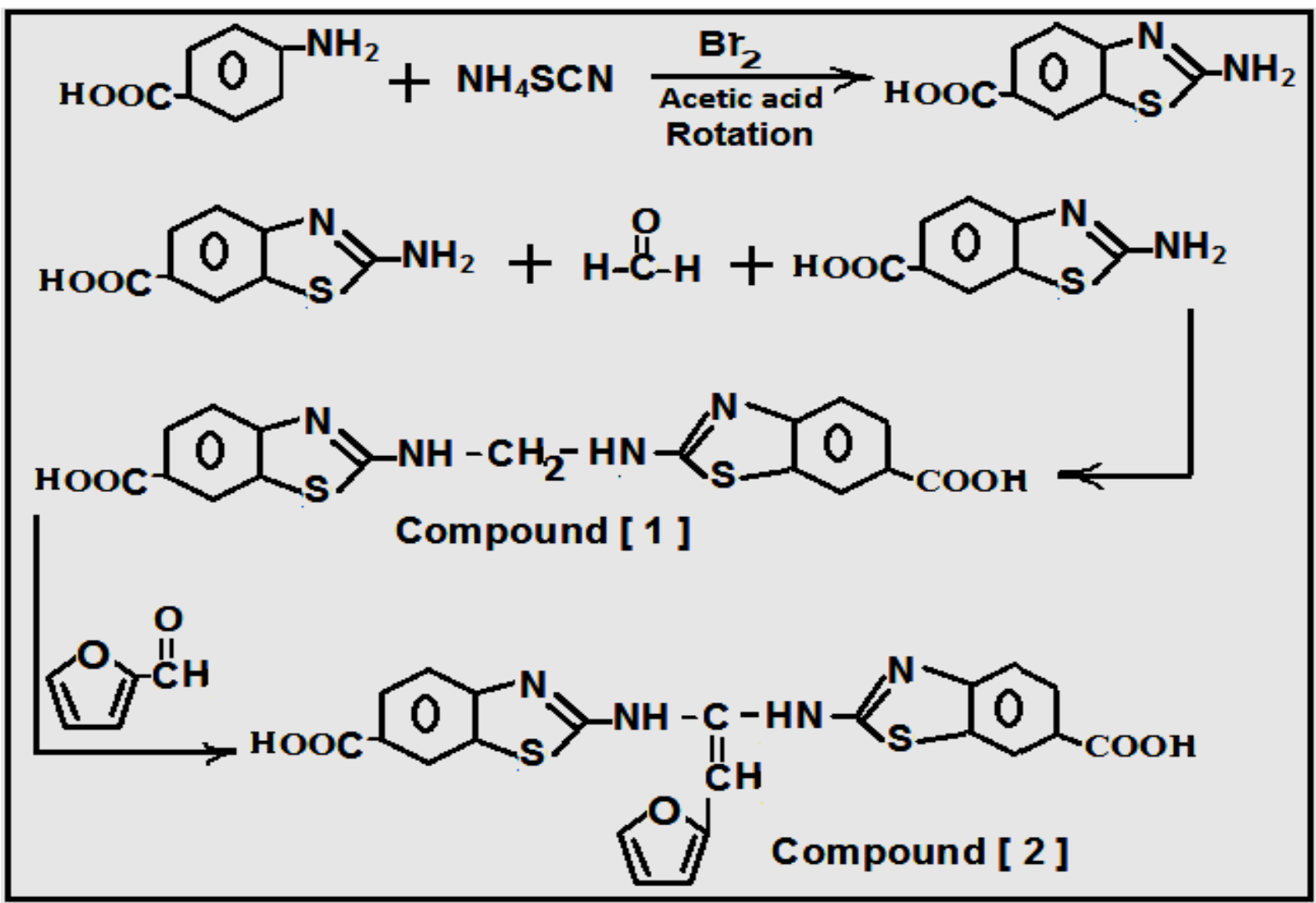

Scheme.1: Synthesis of Compounds $\{1,2\}$

Synthesis of Compounds $3-5\}$ :

Compound $\{2\}\left(0.01\right.$ mole) refluxed with ethanol and $(3 \mathrm{ml})\left(\mathrm{H}_{2} \mathrm{SO}_{4}\right)$ for $(2 \mathrm{hrs})$ to give compound $\{3\}$ as ester, which $(0.1$ mole $)$ refluxed with $(0.2$ mole $)$ of 2 -aminothiazole for $(2 \mathrm{hrs})$ in ethanol as a solvent, then filtered, dried and re crystallized from ethanol to yield compound $\{4\}$., while compound $\{2\}(0.1$ mole $)$ refluxed with ( 0.2 mole ) of 2 -mercaptothiazole for $(3 \mathrm{hrs})$ in ethanol as a solvent according to procedures ${ }^{(38,40)}$, then filtered, dried and re crystallized from ethanol to yield compound $\{5\}$.

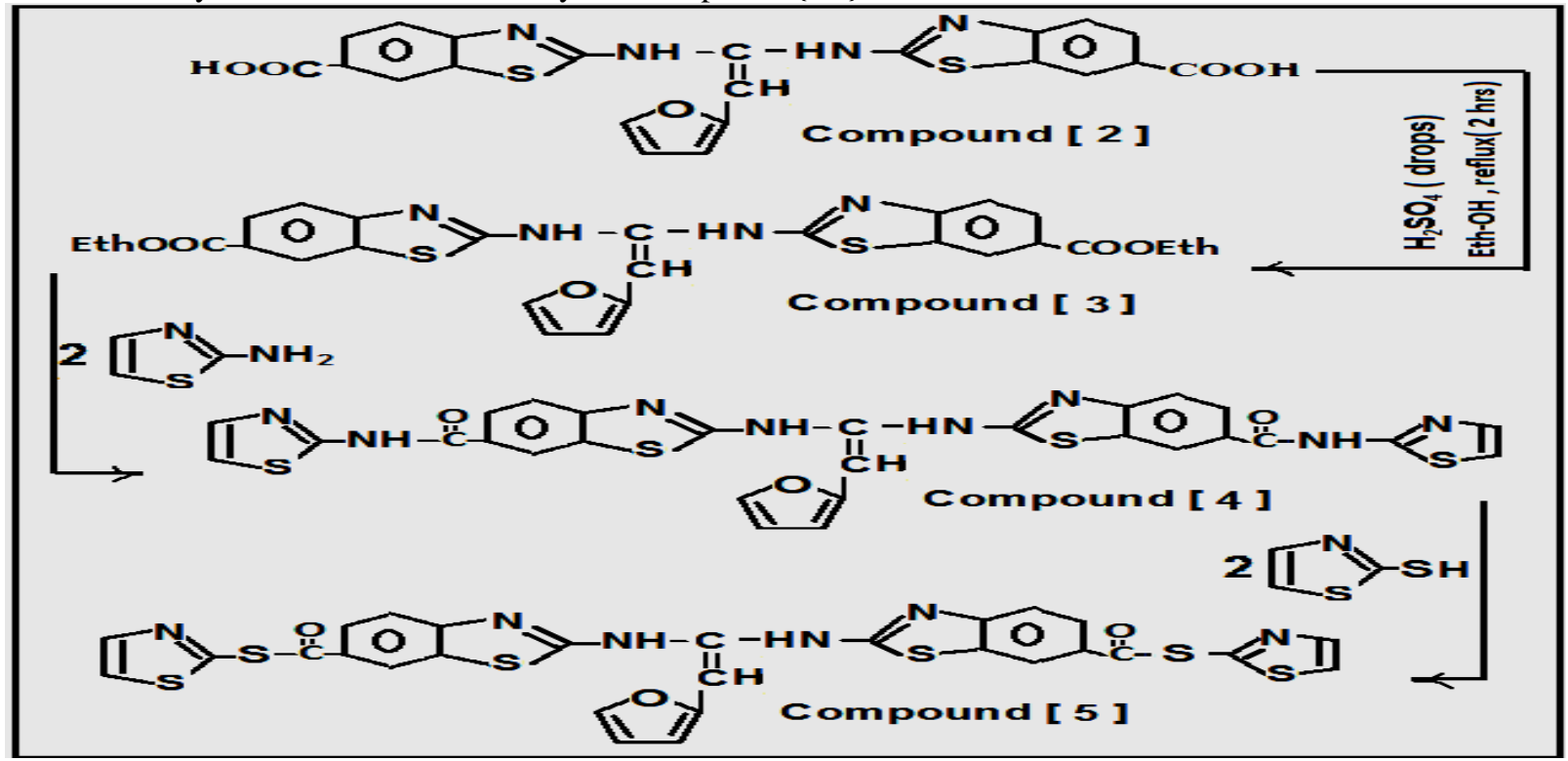

Scheme.2: Synthesis of Compounds $\{3-5\}$ 


\section{Synthesis of Compounds $\{6,7\}$ :}

Diethyl malonate ( 0.2 mole ) dissolved in base medium then refluxed with $(0.1$ mole $)$ of diethylsuccinatewith ethanol for (2 hrs) to give compound $\{6\}$ as ester, which $(0.1$ mole $)$ refluxed with $(0.2$ mole $)$ of semicarbazide for (13 hrs) in ethanol as a solvent and (3 $\mathrm{ml}$ of $\left.\mathrm{H}_{2} \mathrm{SO}_{4}\right)$ according to procedures ${ }^{(21,23)}$, then filtered, dried and re crystallized from ethanol to yield compound $\{7\}$.

Synthesis of Compounds $\{8-10\}$ :

Compound $\{6\}$ (0.1 mole ) refluxed with (0.4mole ) of ortho-phenyl diamine for (7hrs ) with ( $4 \mathrm{~N}$ of $\mathrm{HCl})$, then filtered, dried and re crystallized from ethanol to yield compound $\{8\}$., while compound $\{6\}(0.1$ mole) refluxed with $(0.4$ mole $)$ of ortho-thiol aniline for $(9 \mathrm{hrs})$ with $(4 \mathrm{~N}$ of $\mathrm{HCl})$, then filtered, dried and re crystallized from ethanol to yield compound $\{9\}$., compound $\{6\}$ (0.1 mole ) refluxed with (0.4 mole ) of orthohydroxy aniline for $\left(9 \mathrm{hrs}\right.$ ) with ( $4 \mathrm{~N}$ of $\mathrm{HCl}$ ) according to procedures ${ }^{(21,23)}$, then filtered, dried and re crystallized from ethanol to yield compound $\{10\}$.,

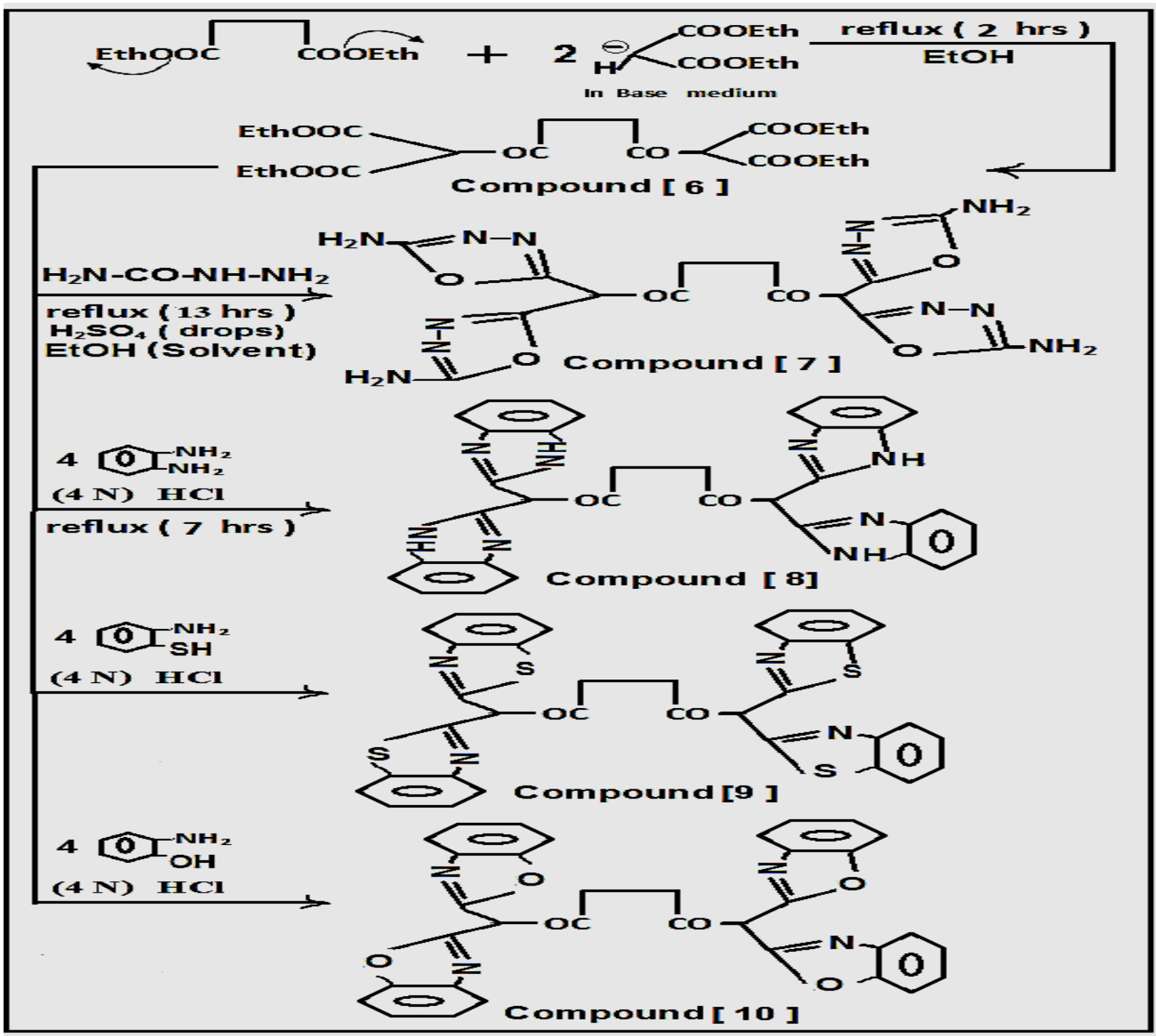

Scheme.3: Synthesis of Compounds $\{6-10\}$

Results and Discussion

Our compounds characterized with many spectral methods like (FT.IR ,H.NMR ,Mass) spectra and with thermal studies: 


\section{Spectral Investigation}

FT.IR- Spectra of Compounds:It appeared many absorption bands appeared at $(\mathrm{C}=\mathrm{N})$ Endocycle: 1641., (CS) endocycle of benzothiazole : 734 ., (-CO-O-) carbonyl of carboxyl group : 1719 ., (NH)Amine group :3270 ., $(\mathrm{OH})$ hydroxyl of carboxyl group: 3120 in compound $\{1\}$, while other bands appeared at $(\mathrm{C}=\mathrm{N})$ Endocycle: 1649., (C-S) endocycle of benzothiazole : 728 ., (-CO-O-) carbonyl of carboxyl group : 1714 ., (NH)Amine group :3276., $(\mathrm{OH})$ hydroxyl of carboxyl group: $3135 .,(\mathrm{CH}=\mathrm{C}): 3100$ in compound $\{2\}$., other bands appeared at $(\mathrm{C}=\mathrm{N})$ Endocycle: 1650., (C-S) endocycle of benzothiazole : 717 ., (-CO-O-) carbonyl of ester group : 1722 ., $(\mathrm{NH})$ Amine group :3262 ., $(\mathrm{CH}=\mathrm{C})$ : 3097 in compound $\{3\}$., but compound $\{4\}$ appeared bands at $(\mathrm{C}=\mathrm{N})$ Endocycle: 1643., (C-S) endocycle of benzothiazole : 729 ., (NH)Amine group :3273 ., $(\mathrm{CH}=\mathrm{C})$ ): 3096 ., (-NHCO) amine of amide : $3204 .,(\mathrm{CO}-\mathrm{N})$ carbonyl of amide : 1689 ,, while compound $\{5\}$ gave bands at $(\mathrm{C}=\mathrm{N})$ Endocycle: 1637., (C-S) endocycle of benzothiazole : 711 ., (NH)Amine group :3264 ., (CH=C ): 3104 .,(CO-S) carbonyl : 1694 ., other bands at (-CO-O-) carbonyl of ester group : 1724 ,,(-CO- $\left.\mathrm{CH}_{2}-\right)$ carbonyl of ketone : 1708 ., (CH-) aliphatic : 2967 in compound $\{6\}$, the spectrum of compound $\{7\}$ appeared bands at (-CO$\left.\mathrm{CH}_{2}-\right)$ carbonyl of ketone : 1713 ., (CH- ) aliphatic : 2985 ., $\left(\mathrm{NH}_{2}\right)$ amine group: $(3245,3266)$.,(C=N) Endocycle of oxadiazole: 1663 ., but bands at (-CO- $\left.\mathrm{CH}_{2}-\right)$ carbonyl of ketone : 1711 ., (CH- ) aliphatic : 2918 ., (NH) amine : 3210 ., (C=N) Endocycle of imidazole: 1656 due to compound $\{8\}$., while appearance of bands at (-CO$\mathrm{CH}_{2}$-) carbonyl of ketone : 1709 ., (CH- ) aliphatic : 2923 ., (C=N) Endocycle of thiazole: 1642 ., (C-S) endocycle of benzothiazole : 753 due to compound $\{9\}$., the compound $\{10\}$ gave bands at $\left(-\mathrm{CO}^{-} \mathrm{CH}_{2}-\right)$ carbonyl of ketone : 1716 ., (CH- ) aliphatic : $2900 .,(\mathrm{C}=\mathrm{N})$ Endocycle of oxazole: 1642 , all bands abstracted in Table (1).

Table (1): FT.IR- data $\left(\mathrm{cm}^{-1}\right)$ of Compounds $\{1-10\}$

\begin{tabular}{|c|c|}
\hline Compounds & Other Groups \\
\hline$\{1\}$ & $\begin{array}{l}(\mathrm{C}=\mathrm{N}) \text { Endocycle: } 1641 .,(\mathrm{C}-\mathrm{S}) \text { endocycle of benzothiazole }: 734 .,(-\mathrm{CO}-\mathrm{O}-) \text { carbonyl of } \\
\text { carboxyl group : } 1719 .,(\mathrm{NH}) \text { Amine group : } 3270 ., \\
(\mathrm{OH}) \text { hydroxyl of carboxyl group: } 3120 .\end{array}$ \\
\hline$\{2\}$ & $\begin{array}{l}(\mathrm{C}=\mathrm{N}) \text { Endocycle: } 1649 .,(\mathrm{C}-\mathrm{S}) \text { endocycle of benzothiazole : } 728 .,(-\mathrm{CO}-\mathrm{O}-) \text { carbonyl of } \\
\text { carboxyl group : } 1714 .,(\mathrm{NH}) \text { Amine group }: 3276 ., \\
(\mathrm{OH}) \text { hydroxyl of carboxyl group: } 3135 .,(\mathrm{CH}=\mathrm{C}): 3100 \text {. }\end{array}$ \\
\hline$\{3\}$ & $\begin{array}{l}(\mathrm{C}=\mathrm{N}) \text { Endocycle: } 1650 .,(\mathrm{C}-\mathrm{S}) \text { endocycle of benzothiazole }: 717 .,(-\mathrm{CO}-\mathrm{O}-) \text { carbonyl of } \\
\text { ester group : } 1722 .,(\mathrm{NH}) \text { Amine group :3262 ., }(\mathrm{CH}=\mathrm{C}): 3097 .\end{array}$ \\
\hline$\{4\}$ & $\begin{array}{l}(\mathrm{C}=\mathrm{N}) \text { Endocycle: } 1643 .,(\mathrm{C}-\mathrm{S}) \text { endocycle of benzothiazole }: 729 .,(\mathrm{NH}) \text { Amine group } \\
: 3273 .,(\mathrm{CH}=\mathrm{C}): 3096 \text {., }(-\mathrm{NH}-\mathrm{CO}) \text { amine of amide }: 3204 .,(\mathrm{CO}-\mathrm{N}) \text { carbonyl of } \\
\text { amide }: 1689 .\end{array}$ \\
\hline$\{5\}$ & $\begin{array}{l}(\mathrm{C}=\mathrm{N}) \text { Endocycle: } 1637 .,(\mathrm{C}-\mathrm{S}) \text { endocycle of benzothiazole }: 711 .,(\mathrm{NH}) \text { Amine group } \\
: 3264 .,(\mathrm{CH}=\mathrm{C}): 3104 .,(\mathrm{CO}-\mathrm{S}) \text { carbonyl }: 1694 .\end{array}$ \\
\hline$\{6\}$ & $\begin{array}{l}\left.\text { (-CO-O-) carbonyl of ester group : } 1724 \text {.,(-CO- } \mathrm{CH}_{2-}\right) \text { carbonyl of ketone : } 1708 \text {., (CH- } \\
\text { ) aliphatic : } 2967 \text {. }\end{array}$ \\
\hline$\{7\}$ & $\begin{array}{l}\left(-\mathrm{CO}-\mathrm{CH}_{2}-\right) \text { carbonyl of ketone : } 1713 .,(\mathrm{CH}-) \text { aliphatic : } 2985 .,\left(\mathrm{NH}_{2}\right) \text { amine group: } \\
(3245,3266) .,(\mathrm{C}=\mathrm{N}) \text { Endocycle of oxadiazole: } 1663 .\end{array}$ \\
\hline$\{8\}$ & $\begin{array}{l}\left(-\mathrm{CO}-\mathrm{CH}_{2}-\right) \text { carbonyl of ketone : } 1711 .,(\mathrm{CH}-) \text { aliphatic : } 2918 .,(\mathrm{NH}) \text { amine }: 3210 \\
.,(\mathrm{C}=\mathrm{N}) \text { Endocycle of imidazole: } 1656 .\end{array}$ \\
\hline$\{9\}$ & $\begin{array}{l}\left.\text { (-CO- } \mathrm{CH}_{2}-\right) \text { carbonyl of ketone : } 1709 .,(\mathrm{CH}-) \text { aliphatic : } 2923 .,(\mathrm{C}=\mathrm{N}) \text { Endocycle of } \\
\text { thiazole: } 1642 .,(\mathrm{C}-\mathrm{S}) \text { endocycle of benzothiazole }: 753 .\end{array}$ \\
\hline$\{10\}$ & $\begin{array}{l}\left.\text { (-CO- } \mathrm{CH}_{2}-\right) \text { carbonyl of ketone : } 1716 .,(\mathrm{CH}-) \text { aliphatic : } 2900 .,(\mathrm{C}=\mathrm{N}) \text { Endocycle of } \\
\text { oxazole: } 1642 \text {. }\end{array}$ \\
\hline
\end{tabular}

${ }^{1}$ H.NMR- Spectra of Compounds

It appeared peaks at 6 DMSO-d6(solvent ): 2.50 ., ( $\left(\mathrm{N}_{-} \mathrm{CH}_{2}-\mathrm{N}-\right)$ Protons : 1.92 ., (NH-): 5.12 ., Protons of Phenyl ring : (6.84-7.89)., (-COOH)proton of carboxyl group of acid: 13.42 in compound $\{1\}$., while it gave signals at(NH-): 5.32 ., Protons of Phenyl ring : (6.67-7.99)., (-COOH)proton of carboxyl group of acid : 13.26 ., $(\mathrm{C}=\mathrm{CH}): 2.41$ in compound $\{2\}$., (., $(\mathrm{NH}-)$ : 5.48 ., Protons of Phenyl ring : (6.84-7.72)., (-COO-Eth)protons of ethyl group :(3.03, 3.27$)$., $(\mathrm{C}=\mathrm{CH}): 2.29$ in compound $\{3\}$., $(\mathrm{NH}-): 5.31$., Protons of Phenyl ring and heterocycles: (6.96-7.64)., (-CO-NH)proton of amide group :10.03 ., $(\mathrm{C}=\mathrm{CH}): 2.10$ in compound $\{4\} .,(\mathrm{NH}-)$ : 5.62 ., Protons of Phenyl ring and heterocycles: (6.75-7.83) ., $(\mathrm{C}=\mathrm{CH}): 2.19$ in compound $\{5\}$., $\left(\mathrm{CO}^{-} \mathrm{CH}_{2}-\right.$ 
$\left.\mathrm{CH}_{2}-\mathrm{CO}\right):(2.00,2.09,2.25)$., (COOEth ): $(3.05-3.37)$ in compound $\{6\}$., $\left(\mathrm{CO}-\mathrm{CH}_{2}-\mathrm{CH}_{2}-\mathrm{CO}\right):(2.08,2.11$, 2.19)., $\left(\mathrm{NH}_{2}\right): 5.67$ in compound $\{7\} .,\left(\mathrm{CO}-\mathrm{CH}_{2}-\mathrm{CH}_{2}-\mathrm{CO}\right):(2.06,2.17,2.29)$., $(\mathrm{NH}): 5.23$., Protons of Phenyl ring : (6.96-7.64) in compound $\{8\}$., $\left(\mathrm{CO}-\mathrm{CH}_{2}-\mathrm{CH}_{2}-\mathrm{CO}\right):(2.13,2.18,2.21)$.,Protons of Phenyl ring : (6.80-7.52) in compound $\{9\} .,\left(\mathrm{CO}-\mathrm{CH}_{2}-\mathrm{CH}_{2}-\mathrm{CO}\right):(2.09,2.17,2.24)$.,Protons of Phenyl ring : $(6.98-7.87)$ in compound $\{10\}$ which give $\left(\mathrm{CO}-\mathrm{CH}_{2}-\mathrm{CH}_{2}-\mathrm{CO}\right):(2.09,2.17,2.24)$.,Protons of Phenyl ring : $(6.98-7.87)$. evidences for preparation of our compounds., and other peaks abstracted in table (2)

Table (2): H.NMR-data ( 5 - ppm) of Compounds $\{1-10\}$

\begin{tabular}{|c|c|}
\hline Compounds & groups \\
\hline$\{1\}$ & $\begin{array}{l}\text { DMSO-d6(solvent ): } 2.50 \text {., }\left(\mathrm{N}-\mathrm{CH}_{2}-\mathrm{N}-\right) \text { Protons : } 1.92 \text {., }(\mathrm{NH}-): 5.12 ., \text { Protons of Phenyl } \\
\text { ring : (6.84-7.89)., (-COOH)proton of carboxyl group of acid : } 13.42 \text {. }\end{array}$ \\
\hline$\{2\}$ & $\begin{array}{l}\text { DMSO-d6(solvent ): } 2.50 .,(\mathrm{NH}-): 5.32 ., \text { Protons of } \text { Phenyl ring : (6.67-7.99)., (- } \\
\text { COOH)proton of carboxyl group of acid : } 13.26 .,(\mathrm{C}=\mathrm{CH}): 2.41 .\end{array}$ \\
\hline$\{3\}$ & $\begin{array}{l}\text { DMSO-d6(solvent ): } 2.50 .,(\mathrm{NH}-): 5.48 \text {., Protons of Phenyl ring : }(6.84-7.72) .,(-\mathrm{COO}- \\
\text { Eth)protons of ethyl group :(3.03, } 3.27) .,(\mathrm{C}=\mathrm{CH}): 2.29 .\end{array}$ \\
\hline$\{4\}$ & $\begin{array}{l}\text { DMSO-d6(solvent ): } 2.50 .,(\mathrm{NH}-): 5.31 ., \text { Protons of Phenyl ring and heterocycles: (6.96- } \\
7.64) .,(-\mathrm{CO}-\mathrm{NH}) \text { proton of amide group }: 10.03 .,(\mathrm{C}=\mathrm{CH}): 2.10 .\end{array}$ \\
\hline$\{5\}$ & $\begin{array}{l}\text { DMSO-d6(solvent ): } 2.50 \text {., (NH-): } 5.62 \text {., Protons of Phenyl ring and heterocycles: (6.75- } \\
7.83) .,(\mathrm{C}=\mathrm{CH}): 2.19 .\end{array}$ \\
\hline$\{6\}$ & $\begin{array}{l}\text { DMSO-d6(solvent ): } 2.50 .,\left(\mathrm{CO}-\mathrm{CH}_{2}-\mathrm{CH}_{2}-\mathrm{CO}\right):(2.00,2.09,2.25) .,(\mathrm{COOEth}):(3.05- \\
\text { 3.37 ). }\end{array}$ \\
\hline$\{7\}$ & DMSO-d6(solvent ): 2.50 ., $\left(\mathrm{CO}-\mathrm{CH}_{2}-\mathrm{CH}_{2}-\mathrm{CO}\right):(2.08,2.11,2.19) .,\left(\mathrm{NH}_{2}\right): 5.67$. \\
\hline$\{8\}$ & $\begin{array}{l}\text { DMSO-d6(solvent }): 2.50,,\left(\mathrm{CO}-\mathrm{CH}_{2}-\mathrm{CH}_{2}-\mathrm{CO}\right):(2.06,2.17,2.29) .,(\mathrm{NH}): 5.23 . \text {, } \\
\text { Protons of Phenyl ring : }(6.96-7.64) .\end{array}$ \\
\hline$\{9\}$ & $\begin{array}{l}\text { DMSO-d6(solvent }): 2.50 \quad,\left(\mathrm{CO}-\mathrm{CH}_{2}-\mathrm{CH}_{2}-\mathrm{CO}\right):(2.13,2.18,2.21) ., \text { Protons of Phenyl } \\
\text { ring : }(6.80-7.52) .\end{array}$ \\
\hline$\{10\}$ & $\begin{array}{l}\text { DMSO-d6(solvent ): } 2.50 \quad,\left(\mathrm{CO}-\mathrm{CH}_{2}-\mathrm{CH}_{2}-\mathrm{CO}\right):(2.09,2.17,2.24) ., \text { Protons of Phenyl } \\
\text { ring : }(6.98-7.87) .\end{array}$ \\
\hline
\end{tabular}

The Mass Spectra of Compounds

There spectra showed good results for formatted compounds and appeared good evidence for their fragments in figures(3-5):

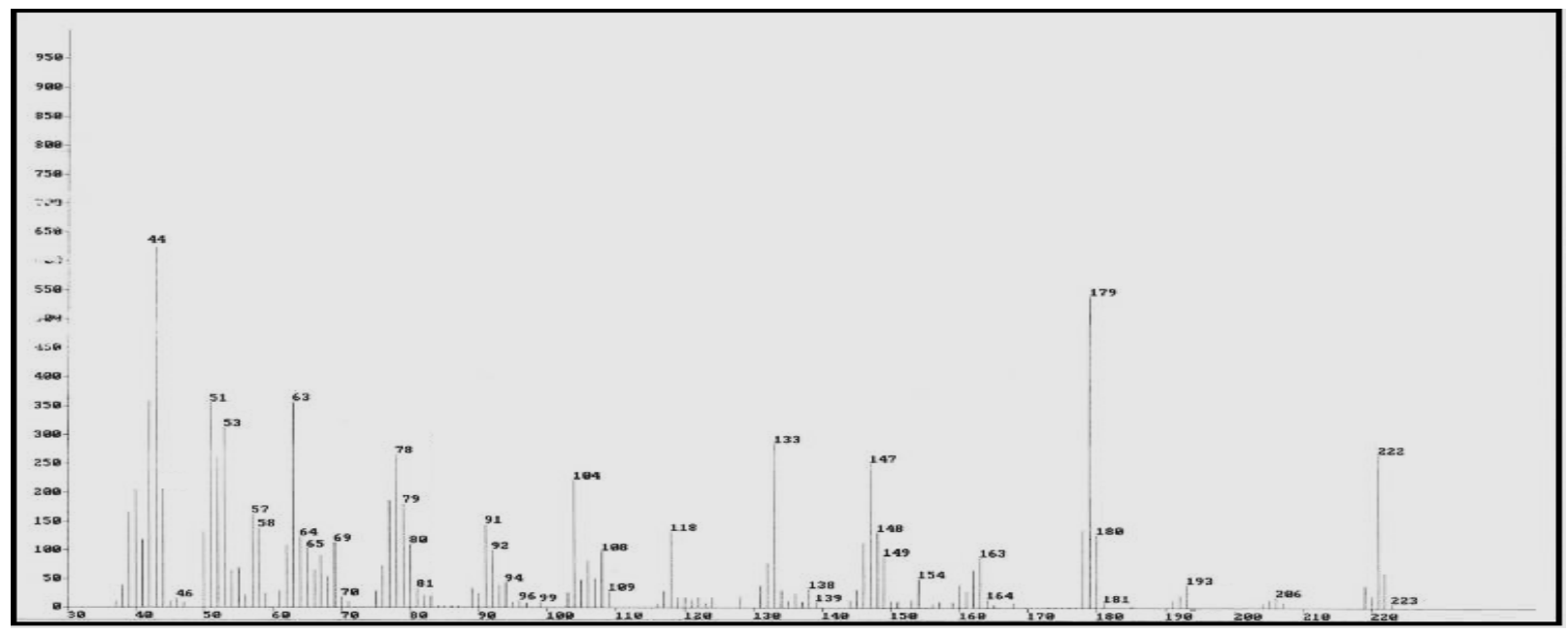

Fig(3): Mass Spectra of Compound $\{5\}$ 


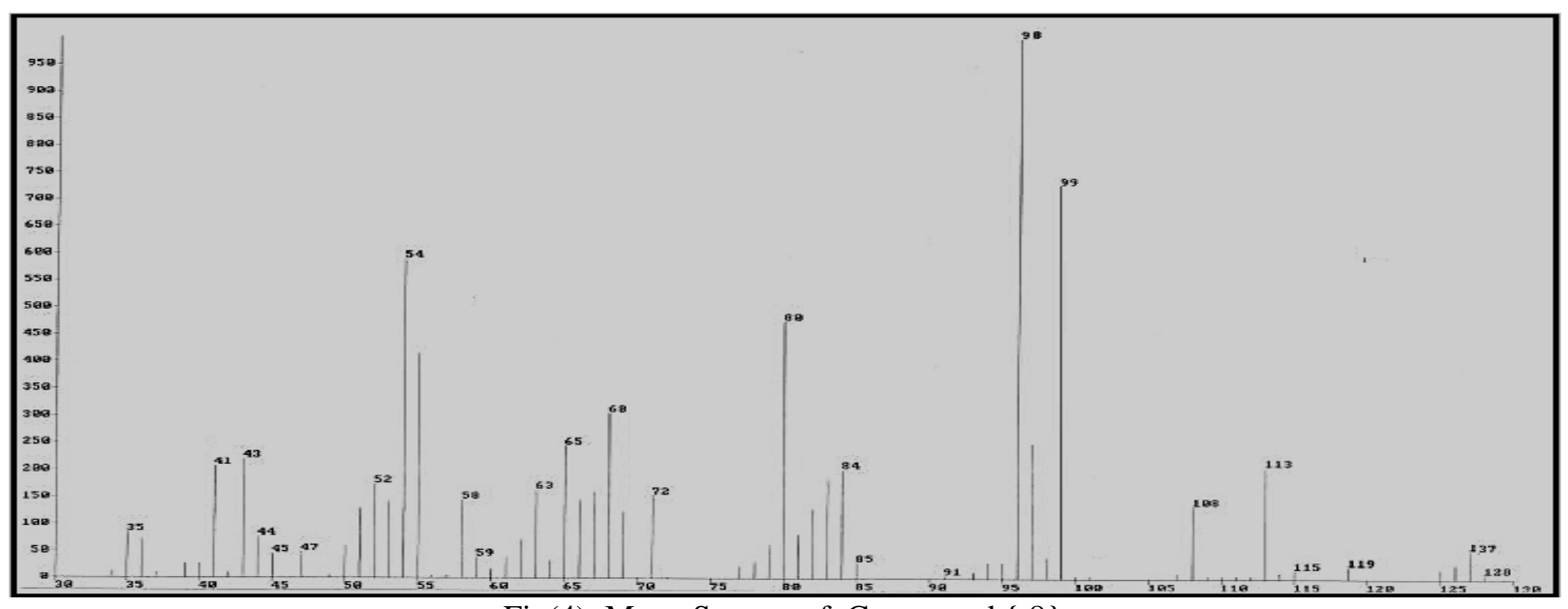

Fig(4): Mass Spectra of Compound $\{8\}$

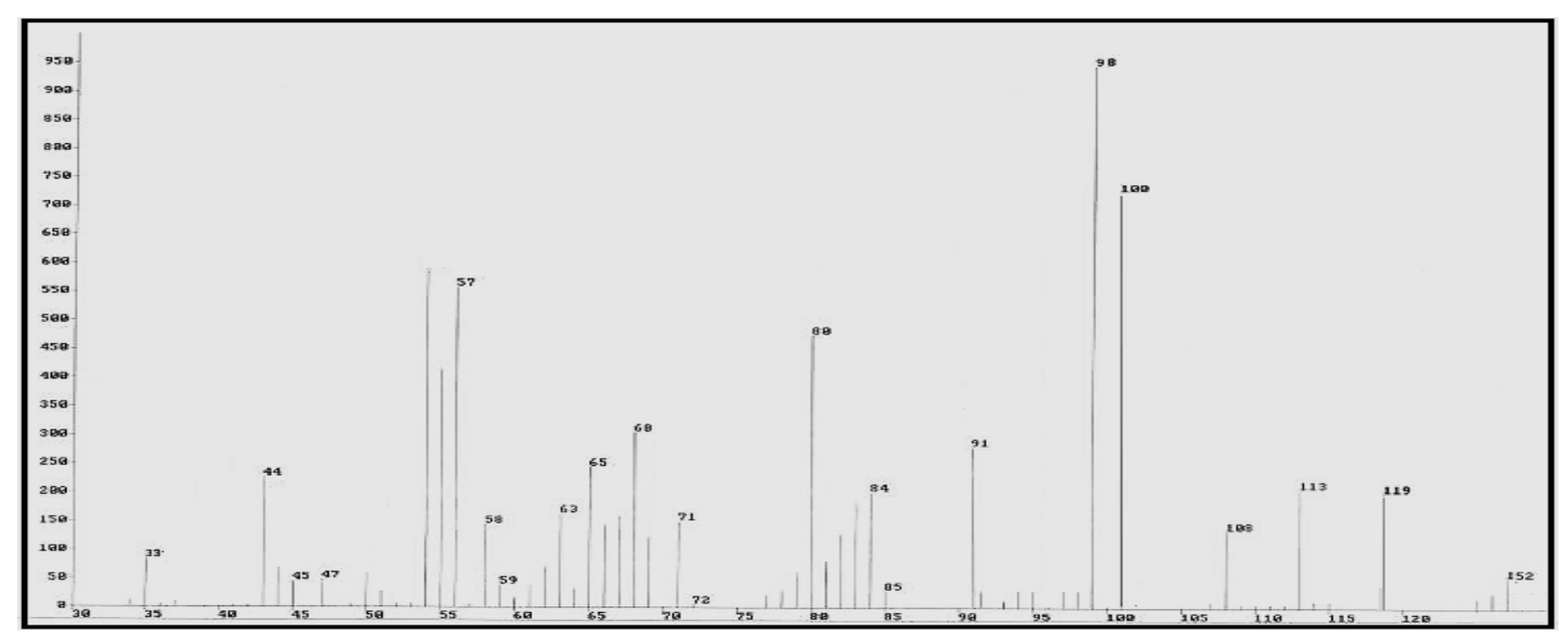

Fig(5): Mass Spectra of Compound $\{10\}$

Thermal - Curves of Compounds

The compounds studied through thermal analysis which appeared stability against different temperatures in figures (6-10) :

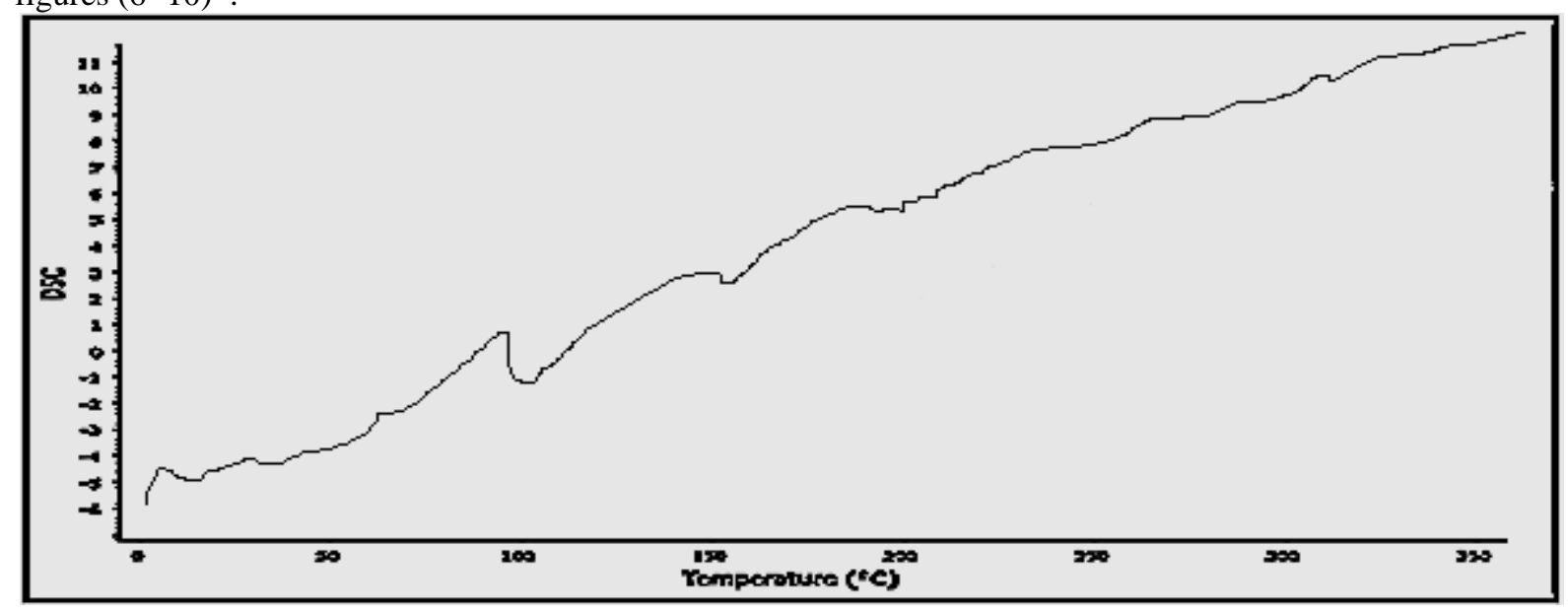

Fig (6) : Thermal Curve of Compound $\{4\}$ 


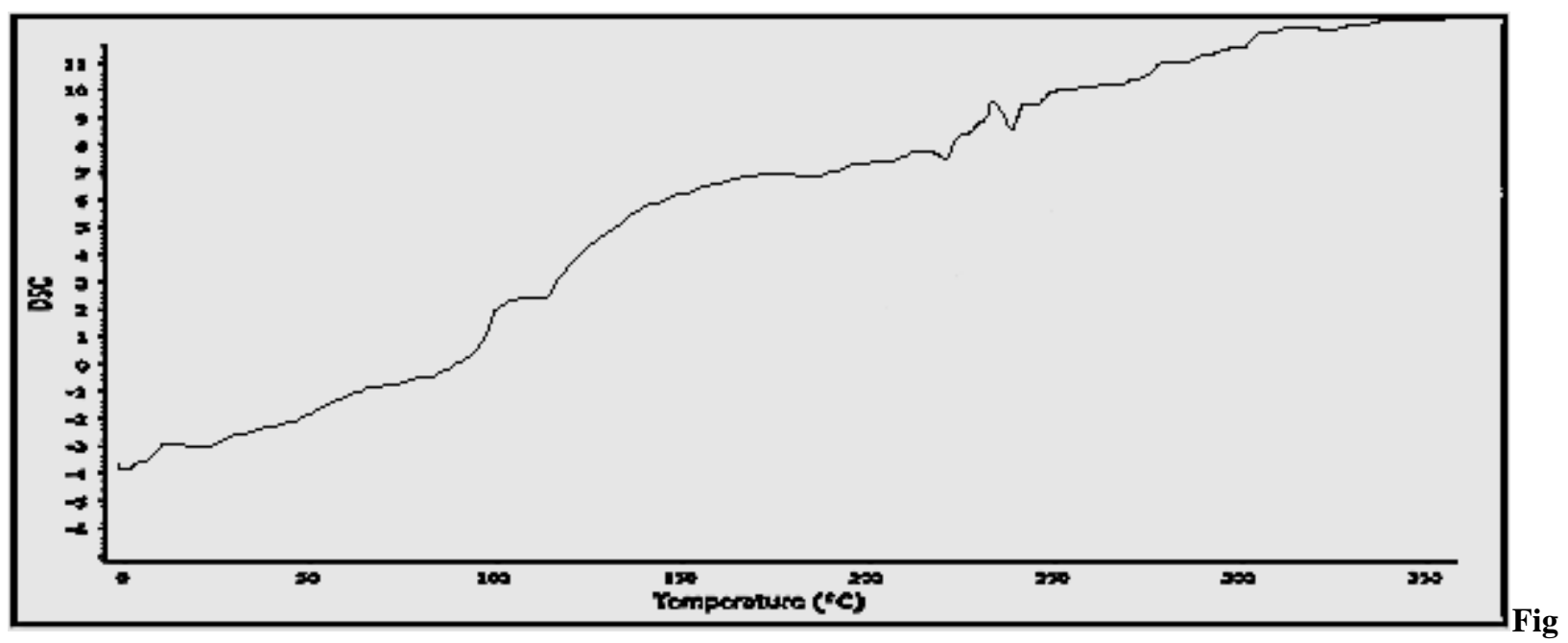

(7) : Thermal Curve of Compound $\{5\}$

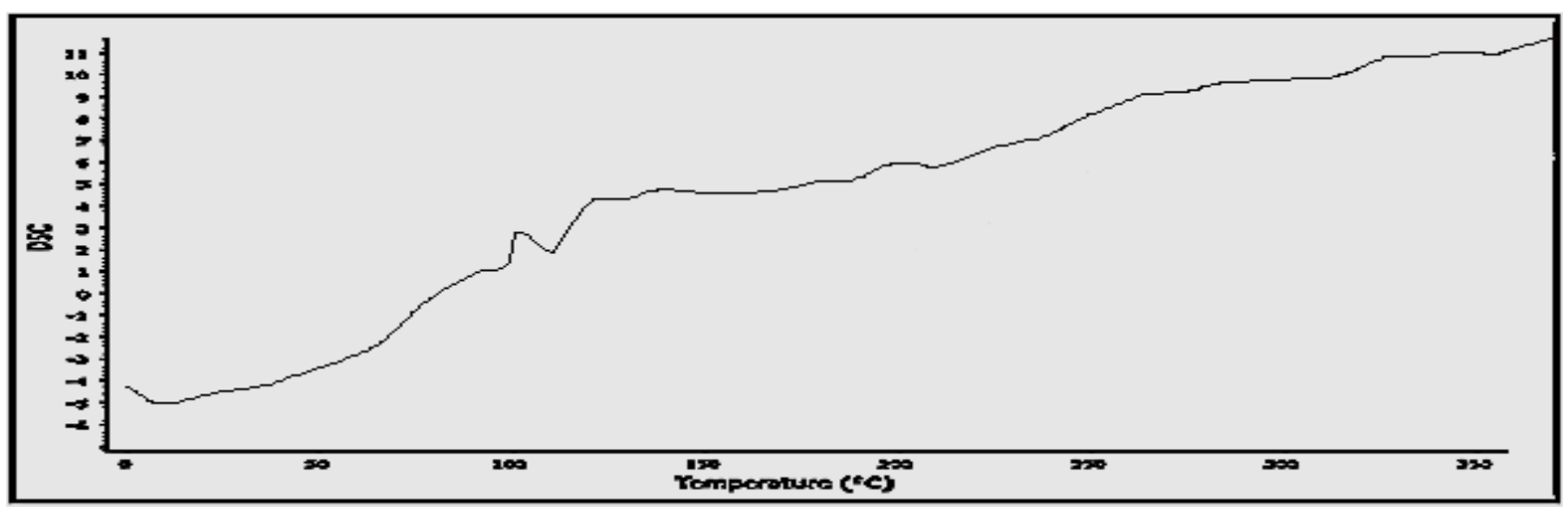

Fig (8): Thermal Curve of Compound $\{8\}$

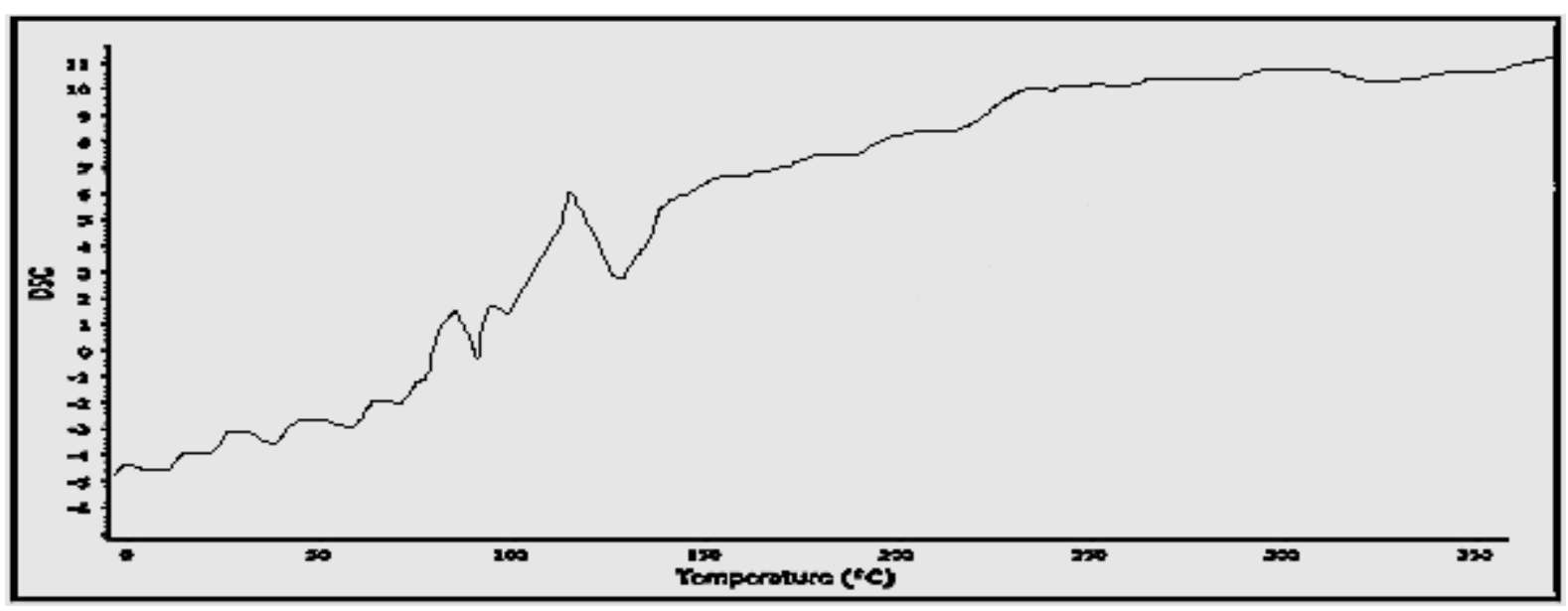

Fig (9): Thermal Curve of Compound $\{9\}$ 


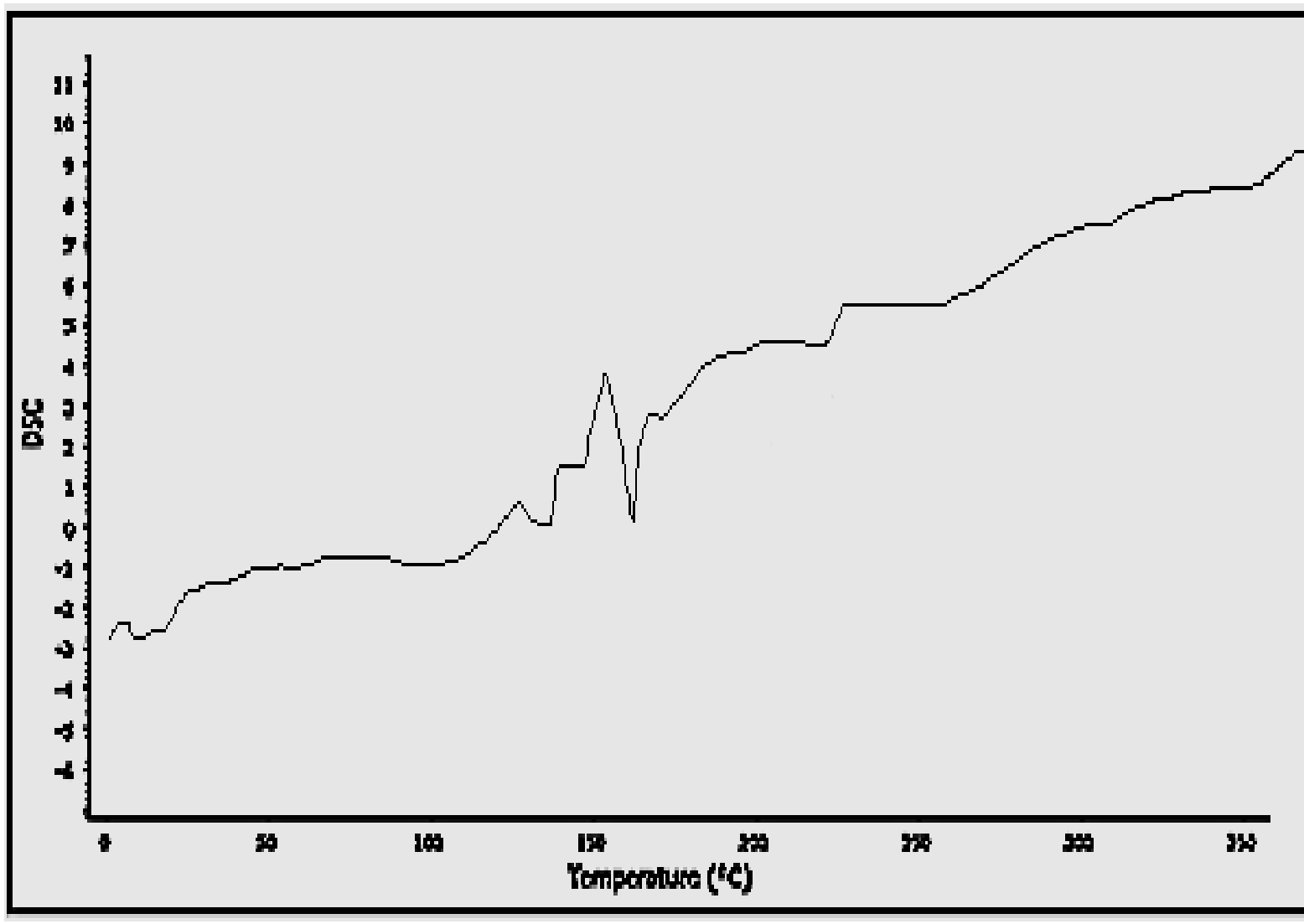

(10): Thermal Curve of Compound $\{10\}$

Solubility of Compounds in Organic Solvents

Test of the solubility of compounds screened with several organic solvents according to (type of solvent, polarity of solvents, activity of functional groups) in compounds, the results abstracted in Table (3).

Table (3) : Behavior of compounds in Solvents

\begin{tabular}{|c|c|c|c|c|c|c|}
\hline \multirow[t]{2}{*}{ Compounds } & \multicolumn{6}{|l|}{ Solvents } \\
\hline & $\mathrm{C}_{2} \mathrm{H}_{5} \mathrm{OH}$ & Methanol & Chloroform & Acetone & Benzene & Toluene \\
\hline ( 1 ) & + & + & - & - & - & - \\
\hline$(2)$ & + & + & - & - & - & - \\
\hline (3) & + & + & - & - & - & - \\
\hline$(4)$ & + & + & - & - & - & - \\
\hline$(5)$ & + & + & - & - & - & - \\
\hline$(6)$ & + & + & - & - & - & - \\
\hline$(7)$ & + & + & - & - & - & - \\
\hline$(8)$ & + & + & - & - & - & - \\
\hline (9) & + & + & - & - & - & - \\
\hline$(10)$ & + & + & - & - & - & - \\
\hline
\end{tabular}

Physical and Chemical Properties of Compound $\{1-10\}$

The Results In Table (4) Appeared Properties And Characterization Like: [( $\left.\mathrm{R}_{\mathrm{f}}\right)$ Of TLC- Technique For Following The Reactions, Type Of Solvent Which Was Used In TLC-Plate, Yield From Reactions \% ], All Data Are Abstracted In Table (4): 
Table(4): Some Physical and Chemical Properties for compounds $\{1-10\}$

\begin{tabular}{llll}
\hline Compounds & Yield $\%$ & $\mathrm{R}_{\mathrm{f}}$ & $\begin{array}{l}\text { Solvents of (TLC) } \\
(1: 2)\end{array}$ \\
\hline $\mathbf{( 1 )}$ & 72 & 0.4 & Ethanol : Benzene \\
\hline $\mathbf{( 2 )}$ & 70 & 0.70 & Ethanol : Benzene \\
\hline $\mathbf{( 3 )}$ & 64 & 0.70 & Ethanol : Benzene \\
\hline $\mathbf{( 4 )}$ & 78 & 0.70 & Ethanol : Benzene \\
\hline $\mathbf{( 5 )}$ & 74 & 0.68 & Ethanol : Benzene \\
\hline $\mathbf{( 6 )}$ & 68 & 0.66 & Ethanol : Benzene \\
\hline $\mathbf{( 7 )}$ & 70 & 0.70 & Ethanol : Benzene \\
\hline $\mathbf{( 8 )}$ & 74 & 0.62 & Ethanol : Benzene \\
\hline $\mathbf{( 9 )}$ & 72 & 068 & Ethanol : Benzene \\
\hline ( 10 $)$ & 76 & 0.64 & Ethanol : Benzene \\
\hline
\end{tabular}

References

1. Jin, J .C.; Baoan, S .; Zhuo, C .; Song, Y.,"Synthesis, structure, and bioactivity of N0-substituted benzylidene3,4,5-Trimethoxybenzo hydrazide and - acetyl-2-substituted phenyl-5-(3,4,5-trimethoxyphenyl)-2,3dihydro-1,3,4-oxadiazole derivatives.", Bioorganic \& Medicinal Chemistry Letters , 2006, 16,5036-504.

2. Aatesh, Ė. ; Kocabalkanli, A. ; Cesur, N . "Synthesis and antimicrobial activity of some 5-aryl-2-[(N,Ndisubstitutedthiocarbamoylthio) acylamino]-1,3,4-oxadiazoles", Farmaco ,1998, 53, 541-544.

3. Clark,M.S.,(2000).,"The bactericidal activity of gemifloxacin. Journal Medical microbial,Vol.49, andp:841-844.

4. Clark, W.G.; Brater, D.C.; Johnson,A.R. (1992).,"Medical pharmacology Goths. Introduction to chemotherapy mechanisms of antibacterial. International edition.

5. Cruickshank, R.; Duguid, J.P.; Matmion B.P. (1973).,"A Guide to the laboratory diagnosis and control of infections. 12Edition . London Vol:1

6. Mims H.M. (1995).Antimicrobial agents and chemo therapy .Medical microbiology Third edition.

7. Sachadev, K.N. (1989). Examination of urine clinical pathology and bacteriology seventh edition. India .

8. Yana, Y; David, M.L. (1998).,"Chromosomal B-lactamase expression and resistance to B-lactam antibiotics in proteus vulgaris and morganellamorganii. Journal Antimicrobial agents and chemotherapy, p:1385-1391.

9. Bramhananda, N. R .; Venkataramudu, B .; Ravindranath, L. K. ; Aleem, S. A. and Narendra , N. S., Der PharmaChemica,2016, 8,4,101-112.

10. Subbiah,R .;Tanmoy,G.; , Tanushree,S .;Puspita, R.; Benu, P.S.;Jayatri, N. ; Avijit, D. and Tapan, K .M., Der PharmaChemica, 2016,8,4,446-452.

11. NaghamMahmoodAljamali .,"Experimental Methods for Preparation of ((Mannich Bases ,Formazan , Normal and Cyclic Sulfur Compounds))".,1 Edt., Evince pub Publishing house, 2018 ., ISBN :97893-87905-19-1.

12. NaghamMahmoodAljamali .,"Reactions and Mechanisms".,1 Edt., IJMRA Publication ,2018 ., ISBN : 978-93-87176-25-6.

13. KiranM. K.; Sagar, A. J.;Pramod, B. P.; Vikas, R. D. andShitalkumar, S. P. , , DerPharmaChemica, 2016, 8,4,15.

14. Chao J .; Huia, P. X .; Lia, Z . "Synthesis and Antibacterial Activities of Novel Biphenyltetrazole Derivatives Bearing 1,3,4- Oxadiazole.” Journal of The Chinese Chemical Society,2005, 52, 539-544 539.

15. Srinivas, K. ;Srinivas, U.;Bhanuprakash, K.;Harakishore, K."Synthesis and antibacterial activity of various substituted s-triazines". Eur J Med Chem ;2006, 41, 1240-1246.

16. Woese, C.R .;Kandler, O.; Wheelis, M.L . "Towards a natural system of organisms: proposal for the domains Archaea, Bacteria, and Eucarya". ,Proceedings of the National Academy of Sciences of the United States of America. , 1990, 87 ,12, 4576-9. 
17. Montalbetti, C. A.; Falque, V. "Amide bond formation and peptide coupling". Tetrahedron., 2005, 61,46, 10827-10852.doi:10.1016/j.tet. 2005.08.031

18. Valeur, E.; Bradley, M. "Amide bond formation: beyond the myth of coupling compounds". Chem. Soc. Rev., 2009, 38,606-631. doi:10.1039/B701677H.

19. Nanjunda S.; Swamy, S.; Basppa, P .B.; Prabhuswamy, B.;Doreswamy, B. H. "Crystal Structure of Novel2butyl-4-chloro-1HImidazolyl-5-Carboxaldehyde" . European Journal. of Medicinal Chemistry , 2006, 41, 531-538.3.

20. Aboraia, S. A.; Rahman, A.M.; Mahouz, M. N.;"Novel 5-(2 hydroxyphenyl)-3-substituted-2,3-dihydro-1,3,4oxadiazole-2-thione derivatives: Promising anticancer agents.”, Bioorganic\& Medicinal Chemistry ,2006, $14,1236-1246$.

21. Mieaad Mohammed, NaghamMahmoodAljamali , Sabreen Ali Abdalrahman , WassanAlaShubber ., "Formation of Oxadiazole Derivatives Ligands from Condensation and Imination Reaction with References To Spectral Investigation, Thermal and Microbial Assay" ., Biochem. Cell. Arch., 2018, 18, 1, pp. 847-853.

22. NaghamMahmoodAljamali. "Synthesis and Biological Study of Hetero (Atoms and Cycles) Compounds", Der PharmaChemica, 2016, 8,6, 40-48.

23. NaghamMahmoodAljamali.; Intisar, O. "Synthesis of Sulfur Heterocyclic Compounds and Study of Expected Biological Activity" ,Research J. Pharm. and Tech., 2015, 8,9 ,1225-1242 ,DOI: 10.5958/0974360X.2015.00224.3.

24. NaghamMahmoodAljamali .;SaherMahmood J.; Zainab MJ .; Seena K."Microbial Studying of (Thiazole ,Oxadiazole, Thiadiazole)-Derivatives on Mouth and Teeth Bacteria ", International Journal of Medical Research and Pharmaceutical Sciences, 2016, 3, 8 ,30-39, DOI:10.5281/zenodo.61357.

25. Rappé, M. S .; Giovannoni, S. J . "The uncultured microbial majority". Annual Review of Microbiology., 2003, 57, 369-94.

26. DeLong, E .F.; Pace, N.R . "Environmental diversity of bacteria and archaea" . Syst Biol. , 2001, $50,4,470-8$.

27. Rosenberg, S.M .; Slack, A . "Antibiotic-induced lateral transfer of antibiotic resistance". Trends Microbiol., 2004, $12,9,401-4$.

28. Gitai, Z . "The new bacterial cell biology: moving parts and subcellular architecture". Cell, $2005,120,5,577-$ 86.

29. Vanita S .; Supriya, M. "Development of furfuraldehydeformazans as potential antitubercular agents " ., Der PharmaChemica, 2016,8,18, 144-148.

30. Park, S.; Park, B.; Yun, S.; Kang, H. and Yun, S. "Antimicrobial activities of honey bee venom against pathogens isolated from clinical bovine mastitis in Korea" , Planta Med., 2013, 79, , PL16.

31. Habibe,T.; Mehmet, L. A . "Electrochemical properties of 1-( $\mathrm{o}^{-}, \mathrm{m}-$, pnitrophenyl)-3-(m-nitrophenyl)-5phenylformazans andtheir nickel complexes" ., Turk J Chem , 2010, 34 , 465 - 479.

32. Angela, K.; Lucica, V.; Nicoleta, C . " Synthesis and structural studies of complexes of Cu, Co, Ni and Zn with isonicotinic acid hydrazide and isonicotinic acid (1-naphthylmethylene)hydrazide", J. Serb. Chem. Soc, 2010, 75 ,2, 229-242.

33. Wright, G.D. " The antibiotic resistome: the nexus of chemical and genetic diversity"., Nature Reviews Microbiology, 2007, 5, 175-186.

34. NaghamMahmoodAljamali . "Synthesis and Chemical Identification of Macro Compounds of (Thiazol and Imidazol)".,Research J. Pharm. and Tech, 2015, 8,1, 78-84., DOI : 10.5958/0974-360X.2015.00016.5 .

35. Hegazi, A.G.; Abdou, A.M. and Abd, A. F. "Evaluation of the antibacterial activity of bee venom from different sources", World Applied Sciences Journal, 2014, 30 ,3, 266-270.

36. Intisar ObaidAlfatlawi, Nuha Salman S, ZainabMahmood J , NaghamMahmoodAljamali, " Synthesis of New Organic Compounds Via Three Components Reaction with Studying of (Identification ,Thermal Behavior, Bioactivity on Bacteria of Teeth) "., Journal of Global Pharma Technology. 2017; 11, 9 ,157164.

37. EmanH. S .,Nagham Mahmood Aljamali .,"New Azo-Thiadiazole Ligands (Preparation, Spectral, Thermal, Biochemical, Physical properties) - Studying " .,Journal of Global Pharma Technology. 2017; 11, 9 ,165.

38.Mieaad Mohamd, Nagham Mahmood Aljamali , Nadheema Abed Abbas ., " Preparation, Spectral Investigation, Thermal Analysis, Biochemical Studying of New (Oxadiazole - Five Membered Ring)-Ligands".,Journal of Global Pharmacy Technology, 2018; 10, 1, 20-29.

39. Intisar ObaidA, Eman HS , Nagham Mahmood Aljamali ., "Synthesis of (Tetrazole, Oxazepine, Azo, Imine) Ligands and Studying of Their (Organic Identification, Chromatography, Solubility, Physical, Thermal Analysis, Bio-Study) " .,Research J. Pharm. and Tech. 11, 7, 2018 . 
40. Mieaad Mohamd, Nagham Mahmood Aljamali , Wassan AlaShubber, Sabreen Ali Abdalrahman .," New Azomethine- Azo Heterocyclic Ligands Via Cyclization of Ester " ., Research J. Pharm. and Tech. 11, 6 , 2018 .,DOI: 10.5958/0974-360X.2018.00472.9 .

Copyrights

Copyright for this article is retained by the author(s), with first publication rights granted to the journal.

This is an open-access article distributed under the terms and conditions of the Creative Commons Attribution license (http://creativecommons.org/licenses/by/4.0/) 